\title{
有明海北東部流入河川の溶存態ケイ素濃度の予測
}

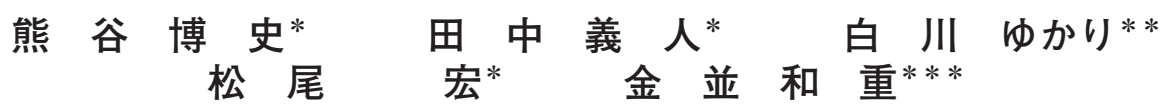

\section{Estimation of Dissolved Silicate Concentration in Influent Rivers of Northeastern Ariake Bay}

\author{
Hiroshi KUMAGAI*, Yoshito TANAKA*, Yukari SHIRAKAWA**, \\ Hiroshi MATSUO* and Kazushige KINNAMI***
}

* Fukuoka Institute of Health and Environmental Sciences, Mukaizano 39, Dazaifu, Fukuoka 811-0135, Japan ** Tagawa Health, Welfare and Environment Office, Matsubaradohri 3292-2, Ida, Tagawa, Fukuoka 825-8277, Japan *** Oita Prefectural Tobu Health Center, Shimotai 14-1, Tsurumi, Beppu, Oita 874-0840, Japan

\begin{abstract}
Dissolved silicate $\left(\mathrm{Si}(\mathrm{OH})_{4}-\mathrm{Si}\right.$; DSi) concentration was examined at 38 sampling sites in influent rivers of the northeastern Ariake Bay, and estimated on the basins of a numerical geological map of the sites' watershed. The multiple regression model was used for predicting DSi concentration at the sampling sites using the geological area ratio in their watersheds. The coefficient of determination $\left(\mathrm{R}^{2}\right)$ obtained was 0.931 , indicating that DSi concentration was strongly associated with its geological condition. The geological categories which contribute to DSi concentration in rivers are quaternary volcanic rocks (non-alkali, felsic), volcanic rocks (debris) and quaternary volcanic rocks (nonalkali, pyroclastic flows). This result suggests that the DSi concentration of an arbitrary station in an influent river of the northeastern Ariake Bay can be predicted on the basins of a geological map of the station.
\end{abstract}

Key words: dissolved silicate, geological map, watershed, Ariake Bay

\section{1.はじめに}

近年, 有明海で生じている環境異変は，同海域の海洋 資源を壞滅させかねず，その原因解明と再生へ向けた対 策は緊急の課題である。有明海・八代海総合調査評価委 員会は, 赤潮発生の一要因として, 有明海における植物 プランクトンの遷移を挙げるとともに, 今後解決すべき 重要な課題として, 赤潮発生の増加に関するメカニズム の更なる解明が必要であるとしている ${ }^{1)}$ 。実際, 有明海 流域では， N・P に関する情報は多くの機関により調査 が実施されているものの, それらに比較すると, 珪藻の 必須栄養塩である溶存珪酸態珪素 $\left(\mathrm{Si}(\mathrm{OH})_{4}-\mathrm{Si}\right.$; 以下溶 存態ケイ素 DSi）についての情報 ${ }^{2)}$ は依然として少ない。

小林 ${ }^{3)}$ は全国各地の河川水を分析し, $\mathrm{SiO}_{2}$ を含む各 項目の平均水質を算出している。その中で有明海流域を 含む九州北部地方では全国に比して $\mathrm{SiO}_{2}$ 濃度が高いこ とを報告している。この理由として, $\mathrm{SiO}_{2}$ 溶出量の多 い阿蘇火山系の火山噴出物が筑後川流域に存在している ことを理由に挙げている。一方で著者ら ${ }^{4)}$ が実施した調 査では, 筑後川本流の DSi 濃度は高かったものの, そ
の他の支川については低濃度のものから, 高濃度のもの まで流域毎に異なっていた。

一般的に河川水中の DSi については，自然由来とさ れており, DSi は河川流域において岩石と水（土壤水, 地下水) が反応し, 岩石から元素を溶解する化学的風化 作用により，河川水中に供給されている。筑後川流域に おいて支流毎にDSi 濃度に変動が見られたのも, 地質 状況が流域毎に異なっていることが原因と考えられる。 すなわち DSi 濃度を予測する際には流域地質の考慮が 必要である。

鹿園 ${ }^{5)}$ は, 化学的風化作用を考慮し, 流出量（runoff： 集水域の単位面積，単位時間当たりの総河川流量）から DSi 濃度を算定する, 水一岩石反応カイネティックスー 流動モデルを提案している。ただしこの方法を用いて DSi 濃度の予測を実施するには, 流出量に加え, 反応比 表面積, 空隙率, リザーバー厚等の多くのパラメータを 必要とする。その為, 本方法を用いて, 有明海流入河川 のように流域毎に地質が異なる状況で DSi 濃度を計算 するのは困難である。

一方, Meybeck ${ }^{6)}$ は, 単一岩石からなる流域を持つ

* 福岡県保健環境研究所 $\overline{7} 811-0135$ 福岡県太宰府市大字向佐野 39

** 福岡県田川保健福祉環境事務所 $\overline{\mathrm{T}} 825-8277$ 福岡県田川市大字伊田松原通り 3292-2

*** 大分県東部保健所 $=874-0840$ 大分県別府市大字鶴見字下田井 14-1 
河川水を調査した上で，地球上の大陸表面の岩石の種類 とその露出面積により, 河川水中の $\mathrm{SiO}_{2}$ と各イオン成 分を見積もっている。その際, 考慮された岩石は花崗岩 等を含む主要 16 種類であるが，それらについての地質 時代は考慮されていない。本研究で対象としている有明 海流域の地質には，第三紀以前に生成された地質と第四 紀地質とが混在する。地質時代は, 岩石の物理的風化作 用にも関わることが考えられる為, 予測の際には地質時 代についても考慮する必要がある。すなわち有明海流域 におけるDSi 濃度を予測し，その負荷量を算出する為 には，空間的に異なる地質及び年代を考慮した，簡便か つ精度の高いモデルが必要となる。

近年では, 流域地質を考慮して「 $\left.\mathrm{SiO}_{2}\right\rfloor$ を求める手法 ${ }^{7)}$ も提案されているが, 流域地質に応じた詳細な河川調査 の実施を必要とする。その為, 本研究の対象領域である 有明海流域のような広域において上記方法を実施するに は多大な労力と経費を要することが予測される。

そこで本研究では, DSi 濃度がその流域地質によって 規定されると仮定した上で，既存地質情報を利用して， 有明海北東部流入河川水中の DSi 濃度の予測を試みた。 先ず流域内の河川水中の DSi 濃度と, それらに対する 流域地質の関連を把握するために, 河川水中の DSi 濃
度実態調査と, 数值地質図を用いた地質調査を実施した。 この結果を用い, 算出した流域地質面積から重回帰分析 を用いて DSi 濃度の再現を試みた。さらにDSi 濃度に 対する影響の高い地質について考察したので報告する。

2. 方法

\section{1 DSi 調査}

毎月一回, 有明海北東部流域に位置する環境基準点・ 補助監視点等で採取された検体を測定した。測定点は

Fig. 1 及び Table 1 (a) に示す 38 地点である。内訳は, 筑 後川流域 19 地点, 矢部川流域 10 地点, 大牟田市内河川 9 地点である。

$\mathrm{DSi}$ の分析は, 試料をメンブレンフィルター （ADVANTEC 社 DISMIC25CS 孔径 $0.45 \mu \mathrm{m}$ ) で滤 過した後, モリブデン黄法 ${ }^{8)}$ またはモリブデン青吸光光 度法 ${ }^{9)}$ を用いた。

なお以降の平均 DSi 濃度の算定に際しては, 地質影 響をみるため, 降雨による希釈と考えられる DSi 濃度 の低下が見られるデータを除外して, 平均值を算出した。

\section{2 地質調査}

前述のように河川水中の DSi 濃度は, 降雨時には表 面流出が卓越し, 浸透水からなる基底流が希釈されるこ

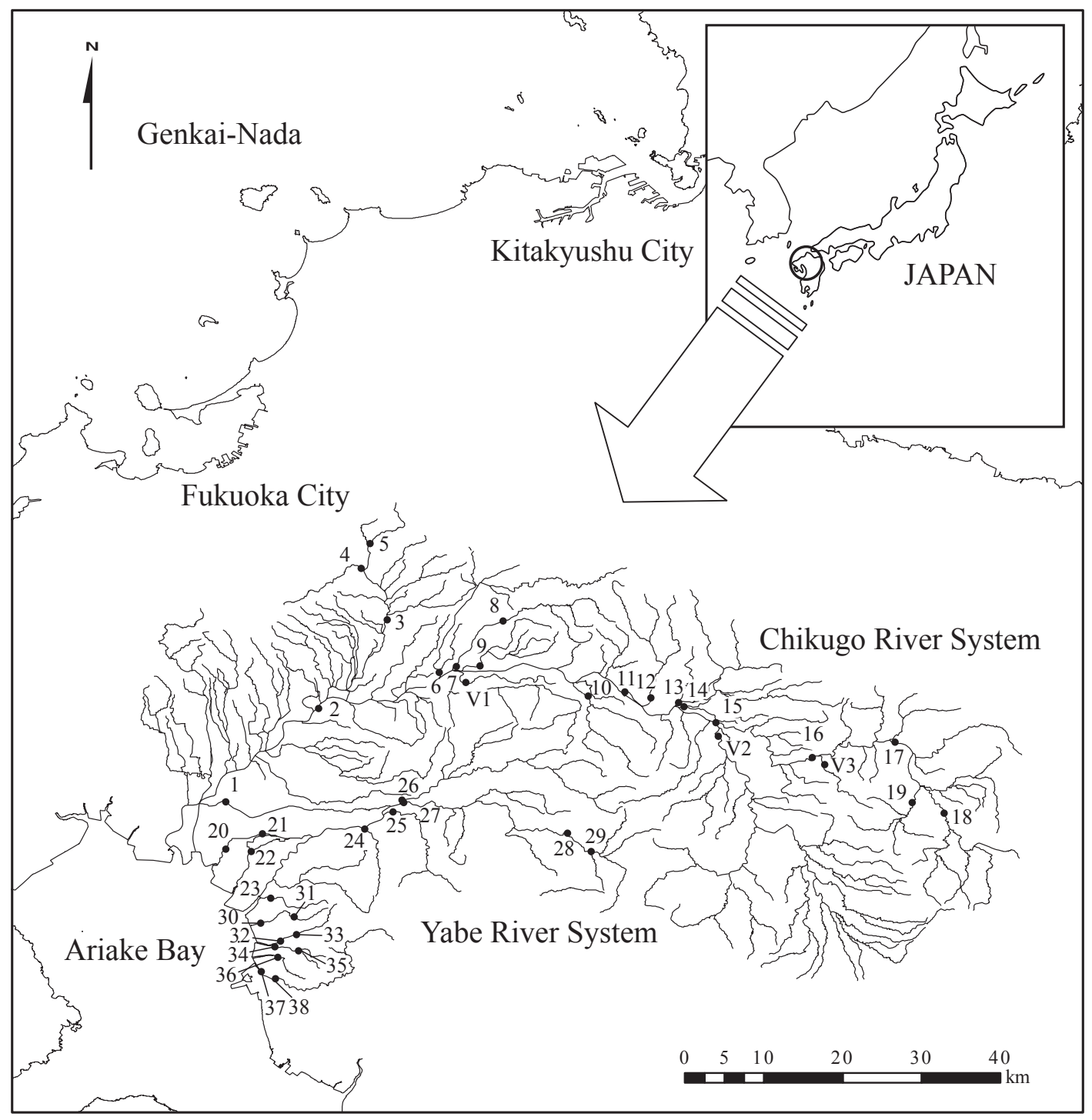

Fig. 1 Map of the study area and locations of the sampling sites. Numbers represent the site numbers in Table 1. 
Table 1 Sampling sites and DSi concentration

(a) Sampling site for calculation

\begin{tabular}{|c|c|c|c|c|c|c|c|c|c|c|c|c|c|}
\hline \multirow{2}{*}{ Site No. } & \multirow{2}{*}{ Sampling site } & \multirow{2}{*}{ River system } & \multirow{2}{*}{ River } & \multicolumn{6}{|c|}{ Location (WGS84) } & \multirow{2}{*}{ Sampling period } & \multirow{2}{*}{$\begin{array}{c}\text { Mean } \\
\left(\mathrm{mg} \cdot \ell^{-1}\right)\end{array}$} & \multirow{2}{*}{$\begin{array}{c}\text { S.D. } \\
\left(\mathrm{mg} \cdot \ell^{-1}\right)\end{array}$} & \multirow{2}{*}{$\mathrm{n}$} \\
\hline & & & & \multicolumn{3}{|c|}{ Latitude } & \multicolumn{3}{|c|}{ Longitude } & & & & \\
\hline 1 & Sakemi Bridge & \multirow{19}{*}{ Chikugo R. } & Hanamune R. & $33^{\circ}$ & $11^{\prime} 2^{\prime}$ & $45^{\prime \prime}$ & $130^{\circ}$ & $23^{\prime}$ & $22^{\prime \prime}$ & Jun. 2006-Mar. 2009 & 6.4 & 2.3 & 35 \\
\hline 2 & Senoshita & & Chikugo R. & $33^{\circ}$ & $18^{\circ}$ & $54^{\prime \prime}$ & $130^{\circ}$ & $29^{\circ}$ & $18^{\prime \prime}$ & Jun. 2006-Mar. 2009 & 15.0 & 2.4 & 33 \\
\hline 3 & Onigawara Bridge & & Houman R. & $33^{\circ}$ & $25^{\circ}$ & $13^{\prime \prime}$ & $130^{\circ}$ & $34^{\prime}$ & $25^{\prime \prime}$ & Jun. 2006-Mar. 2009 & 9.5 & 1.7 & 36 \\
\hline 4 & Nagaoka Bridge & & Houman R. & $33^{\circ}$ & $28^{\circ}$ & $47^{\prime \prime}$ & $130^{\circ}$ & $32^{\prime}$ & $38^{\prime \prime}$ & Jun. 2006-Mar. 2009 & 9.8 & 2.3 & 34 \\
\hline 5 & Iwamoto Bridge & & Houman R. & $33^{\circ}$ & $30^{\circ}$ & $26^{\prime \prime}$ & $130^{\circ}$ & $33^{\prime}$ & $14^{\prime \prime}$ & Jun. 2006-Mar. 2009 & 9.3 & 1.0 & 34 \\
\hline 6 & Takanari Bridge & & Koishihara R. & $33^{\circ}$ & $21^{\circ}$ & $38^{\prime \prime}$ & $130^{\circ}$ & $37^{\prime}$ & $59^{\prime \prime}$ & Jun. 2006-Mar. 2009 & 8.7 & 2.1 & 34 \\
\hline 7 & Sadagawa Bridge & & Sada R. & $33^{\circ}$ & $22^{\prime}$ & $3^{\prime \prime}$ & $130^{\circ}$ & $39^{\circ}$ & $7^{\prime \prime}$ & Jun. 2006-Mar. 2009 & 6.2 & 1.2 & 36 \\
\hline 8 & Yakatabaru Bridge & & Yakatabaru R. & $33^{\circ}$ & $25^{\prime}$ & $10^{\prime \prime}$ & $130^{\circ}$ & $42^{\prime}$ & $21^{\prime \prime}$ & Jun. 2006-Mar. 2009 & 5.2 & 1.0 & 36 \\
\hline 9 & Hinashiro Bridge & & Katsura R. & $33^{\circ}$ & $22^{\prime}$ & $3 "$ & $130^{\circ}$ & $40^{\circ}$ & $41^{\prime \prime}$ & Jun. 2006-Mar. 2009 & 13.3 & 2.5 & 36 \\
\hline 10 & Nagino Bridge & & Kumanoue R. & $33^{\circ}$ & $19^{\circ}$ & $59^{\prime \prime}$ & $130^{\circ}$ & $48^{\circ}$ & $10^{\prime \prime}$ & Jun. 2006-Mar. 2009 & 12.3 & 2.3 & 34 \\
\hline 11 & Yoake Dam & & Chikugo R. & $33^{\circ}$ & $20^{\circ}$ & $15^{\prime \prime}$ & $130^{\circ}$ & $29^{\circ}$ & $39^{\prime \prime}$ & Jun. 2007-Mar. 2009 & 18.1 & 2.2 & 22 \\
\hline 12 & Chayanose Bridge & & Ohi R. & $33^{\circ}$ & $19^{\prime}$ & $28^{\prime \prime}$ & $130^{\circ}$ & $52^{\prime}$ & $11^{\prime \prime}$ & Apr. 2008-Mar. 2009 & 13.5 & 1.6 & 12 \\
\hline 13 & Saburoumaru Bridge & & Kagetsu R. & $33^{\circ}$ & $19^{\circ}$ & $34^{\prime \prime}$ & $130^{\circ}$ & $54^{\prime}$ & $23^{\prime \prime}$ & Apr. 2008-Mar. 2009 & 13.8 & 1.8 & 12 \\
\hline 14 & Nagafuchi Bridge & & Shote R. & $33^{\circ}$ & $19^{\circ}$ & $15^{\prime \prime}$ & $130^{\circ}$ & $54^{\prime}$ & $29^{\prime \prime}$ & Apr. 2008-Mar. 2009 & 19.2 & 1.5 & 12 \\
\hline 15 & Kobuchi Bridge & & Kusu R. & $33^{\circ}$ & $18^{\prime}$ & $10^{\prime \prime}$ & $130^{\circ}$ & $56^{\prime}$ & $56^{\prime \prime}$ & Apr. 2008-Mar. 2009 & 20.5 & 1.5 & 12 \\
\hline 16 & Ichinomura Bridge & & Kusu R. & $33^{\circ}$ & $15^{\circ}$ & $48^{\prime \prime}$ & $131^{\circ}$ & $3^{\prime}$ & $27^{\prime \prime}$ & Apr. 2008-Mar. 2009 & 22.1 & 2.3 & 12 \\
\hline 17 & Kyoushin Bridge & & Kusu R. & $33^{\circ}$ & $16^{\prime}$ & $46^{\prime \prime}$ & $131^{\circ}$ & $9^{\prime}$ & $8 "$ & Apr. 2008-Mar. 2009 & 22.3 & 2.3 & 12 \\
\hline 18 & Higashikochi Bridge & & NarukoR. & $33^{\circ}$ & $10^{\prime}$ & $56 "$ & $131^{\circ}$ & $12^{\prime}$ & $51^{\prime \prime}$ & Apr. 2008-Mar. 2009 & 25.8 & 2.2 & 12 \\
\hline 19 & Kuguriishi Bridge & & Machida R. & $33^{\circ}$ & $12^{\prime}$ & $43^{\prime \prime}$ & $131^{\circ}$ & $10^{\prime}$ & $20 "$ & Apr. 2008-Mar. 2009 & 27.0 & 3.5 & 12 \\
\hline 20 & Miake Bridge & \multirow{10}{*}{ Yabe R. } & Okinohata R. & $33^{\circ}$ & $9^{\prime}$ & $32 "$ & $130^{\circ}$ & $23^{\prime}$ & $25^{\prime \prime}$ & May 2006-Mar. 2009 & 7.4 & 1.2 & 35 \\
\hline 21 & Isodori Weir & & Okinohata R. & $33^{\circ}$ & $10^{\prime}$ & $35^{\prime \prime}$ & $130^{\circ}$ & $25^{\prime}$ & $53^{\prime \prime}$ & May 2006-Mar. 2009 & 6.3 & 1.7 & 35 \\
\hline 22 & Seiten Bridge & & Shiotsuka R. & $33^{\circ}$ & $9^{\prime}$ & $26^{\prime \prime}$ & $130^{\circ}$ & $25^{\prime}$ & $7^{\prime \prime}$ & May 2006-Mar. 2009 & 7.3 & 1.6 & 35 \\
\hline 23 & Sankaizeki Bridge & & Kusuda R. & $33^{\circ}$ & $12^{\prime}$ & $39^{\prime \prime}$ & $130^{\circ}$ & $35^{\prime}$ & $22 "$ & May 2006-Mar. 2009 & 7.9 & 2.0 & 35 \\
\hline 24 & Yamashita Bridge & & Shiraki R. & $33^{\circ}$ & $10^{\circ}$ & $53^{\prime \prime}$ & $130^{\circ}$ & $32^{\prime}$ & $54^{\prime \prime}$ & May 2006-Mar. 2009 & 5.9 & 0.7 & 35 \\
\hline 25 & Nakadouri Bridge & & Hebaru R. & $33^{\circ}$ & $12^{\prime}$ & $3^{\prime \prime}$ & $130^{\circ}$ & $34^{\prime}$ & $47^{\prime \prime}$ & May 2006-Mar. 2009 & 6.4 & 0.7 & 35 \\
\hline 26 & Kamiyabegawa Bridge & & Hoshino R. & $33^{\circ}$ & $12^{\prime}$ & $42^{\prime \prime}$ & $130^{\circ}$ & $35^{\prime}$ & $19^{\prime \prime}$ & May 2006-Mar. 2009 & 8.1 & 0.9 & 35 \\
\hline 27 & Hoshinogawa Bridge & & Hoshino R. & $33^{\circ}$ & $12^{\prime}$ & $42^{\prime \prime}$ & $130^{\circ}$ & $35^{\prime}$ & $19^{\prime \prime}$ & May 2006-Mar. 2009 & 7.7 & 0.7 & 35 \\
\hline 28 & Matsuze Dam & & Yabe R. & $33^{\circ}$ & $10^{\circ}$ & $32 "$ & $130^{\circ}$ & $46^{\prime}$ & $6 "$ & Apr. 2006-Mar. 2009 & 7.9 & 1.0 & 36 \\
\hline 29 & Manotsuru Bridge & & Yabe R. & $33^{\circ}$ & $9^{\prime}$ & $18^{\prime \prime}$ & $130^{\circ}$ & $48^{\prime}$ & $39^{\prime \prime}$ & May 2006-Mar. 2009 & 8.1 & 1.1 & 36 \\
\hline 30 & Miikekantakunai Bridge & \multirow{2}{*}{ Kuma R. } & \multirow{2}{*}{ Kuma R. } & $33^{\circ}$ & $4^{\prime}$ & $31^{\prime \prime}$ & $130^{\circ}$ & $25^{\prime}$ & $45^{\prime \prime}$ & Sep. 2006-Mar. 2009 & 7.7 & 1.8 & 36 \\
\hline 31 & Tsukazaki Bridge & & & $33^{\circ}$ & $4^{\prime}$ & $54^{\prime \prime}$ & $130^{\circ}$ & $28^{\prime}$ & $0 "$ & Sep. 2006-Mar. 2009 & 10.5 & 2.1 & 36 \\
\hline 32 & Shinkawa Bridge & \multirow{2}{*}{ Shiragane R. } & \multirow{2}{*}{ Shiragane R. } & $33^{\circ}$ & $3^{\prime}$ & $5 "$ & $130^{\circ}$ & $50^{\prime}$ & $50 "$ & Sep. 2006-Mar. 2009 & 8.2 & 2.4 & 36 \\
\hline 33 & Miikedenryokusyoyokoi Weir & & & $33^{\circ}$ & $3^{\prime}$ & $40^{\prime \prime}$ & $130^{\circ}$ & $12^{\prime}$ & $12^{\prime \prime}$ & Sep. 2006-Mar. 2009 & 9.5 & 1.6 & 36 \\
\hline 34 & Shindoumen Bridge & \multirow{2}{*}{ Doumen R. } & \multirow{2}{*}{ Doumen R. } & $33^{\circ}$ & $2^{\prime}$ & $55^{\prime \prime}$ & $130^{\circ}$ & $26^{\prime}$ & $38^{\prime \prime}$ & Sep. 2006-Mar. 2009 & 9.4 & 1.5 & 36 \\
\hline 35 & Okogaeri Bridge & & & $33^{\circ}$ & $2^{\prime}$ & $37^{\prime \prime}$ & $130^{\circ}$ & $28^{\prime}$ & $21^{\prime \prime}$ & Sep. 2006-Mar. 2009 & 11.2 & 1.8 & 36 \\
\hline 36 & Satsuki Bridge & Omuta R. & Omuta R. & $33^{\circ}$ & $2^{\prime}$ & $6 "$ & $130^{\circ}$ & $26^{\prime}$ & $53^{\prime \prime}$ & Sep. 2006-Mar. 2009 & 10.9 & 2.7 & 36 \\
\hline 37 & Miiketetsudoukako Bridge & $\mathrm{F}$ & $1 \mathrm{~s}$ & $33^{\circ}$ & $1^{\prime}$ & $20 "$ & $130^{\circ}$ & $25^{\prime}$ & $39^{\prime \prime}$ & Sep. 2006-Mar. 2009 & 12.9 & 3.2 & 36 \\
\hline 38 & Babamachishusui Weir & & & $33^{\circ}$ & $0^{\prime}$ & $40^{\prime \prime}$ & $130^{\circ}$ & $26^{\prime}$ & $31^{\prime \prime}$ & Sep. 2006-Mar. 2009 & 15.9 & 2.7 & 36 \\
\hline
\end{tabular}

(b) Sampling site for validation

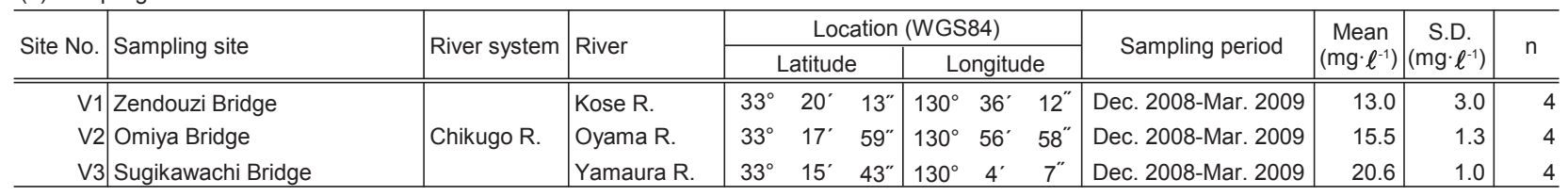

とにより減少する ${ }^{10)}$ 。しかし非降雨時においては, 浸透 水中の DSi 濃度の変動や, その他の流入負荷, 水中で の増減が無ければ, 河川水中の DSi 濃度はほぼ一定で あり，この基底流に含まれるDSi の多鿒が非降雨時の 河川水中の DSi 濃度を規定すると考えられる。本研究 では,この河川の基底流に影響を与える表層地質情報が 必要である。

日本における表層地質情報としては，産業技術総合研 究所地質調査総合センターにより数值地質図が整備され ている。ここでは研究対象流域を全て網羅している 100 万分の 1 の数值地質図 ${ }^{11)}$ を利用した。同地質図におい ては, 地質単位には地層 (群) 名や岩帯名が付されてい ないものの, 区分内容が直感的に理解可能なようにマト リクス方式で記載されており, 岩相・地質時代によって 165 のカテゴリーに区分されている。本研究では, 火山
岩類（非アルカリ）については岩相と地質時代（第三紀 以前及び第四紀）で区分した。それ以外については，地 質時代が確定している岩相を除き，地質時代を考慮せず 岩相のみで分類した。これにより全地質を 22 分類に区 分した (Table 2)。なお, ここに記載してある火山岩類 (岩 屑）［Cat.6] とは，第四紀に生成した岩屑ながれ，火山 麓扇状地, 火山泥流, 小規模火砕流などの堆積物が含ま れている。

各流域については, 国土数值情報の流路 ${ }^{12)}$ ・流域 ${ }^{13)}$ に従い分割した。観測地点付近の流域の修正については, 2 万 5 千分の 1 数值地図を利用した。

以上の情報を用いて各地点の流域界を決定した後に, ESRI 社 ArcGIS9.0 を用いて, 流域界によって数值地質 四をクリップし，流域界に含まれる各地質面積を集計し た。 
Table 3 Ratio of divided areas by geological categories in catchment basin of sampling sites

(a) Sampling site for calculation

\begin{tabular}{|c|c|c|c|c|c|c|c|c|c|c|c|c|c|c|c|c|c|c|}
\hline \multicolumn{17}{|c|}{ ling } & \\
\hline \multirow{2}{*}{ Site No. } & \multirow{2}{*}{ Sampling site } & \multirow{2}{*}{$\begin{array}{c}\text { Tota area } \\
\left(\mathrm{km}^{2}\right) \\
\end{array}$} & \multicolumn{14}{|c|}{ Ratio of divided areas by geological categories (-) } & \multirow{2}{*}{$\begin{array}{l}\text { Observed } \\
\text { DSi value } \\
\end{array}$} & \multirow{2}{*}{$\begin{array}{l}\text { Predicted } \\
\text { DSi value }\end{array}$} \\
\hline & & & 1 & 4 & 6 & 8 & 9 & 10 & 12 & 13 & 16 & 17 & 18 & 20 & 21 & 22 & & \\
\hline 1 & Sakemi Bridge & 407.8 & 0.141 & - & - & - & - & 0.010 & - & 0.446 & - & - & - & - & 0.398 & 0.005 & 6.4 & 8.7 \\
\hline 2 & Senoshita & 2270.1 & 0.187 & - & 0.004 & 0.064 & 0.002 & 0.201 & 0.136 & 0.241 & 0.078 & - & $<0.001$ & $<0.001$ & 0.084 & 0.002 & 15.0 & 15.3 \\
\hline 3 & Onigawara Bridge & 139.9 & 0.405 & - & - & - & - & - & - & - & 0.542 & - & - & - & 0.054 & - & 9.5 & 10.2 \\
\hline 4 & Nagaoka Bridge & 22.7 & 0.149 & - & - & - & - & - & - & - & 0.851 & - & - & - & - & - & 9.8 & 10.5 \\
\hline 5 & Iwamoto Bridge & 16.5 & 0.084 & - & - & - & - & - & - & - & 0.855 & - & - & - & 0.061 & - & 9.3 & 10.2 \\
\hline 6 & Takanari Bridge & 90.5 & 0.282 & - & - & - & - & - & - & 0.012 & 0.150 & - & 0.012 & - & 0.533 & 0.010 & 8.7 & 7.9 \\
\hline 7 & Sadagawa Bridge & 72.3 & 0.262 & - & - & - & - & - & - & 0.019 & 0.023 & - & - & - & 0.696 & - & 6.2 & 7.1 \\
\hline 8 & Yakatabaru Bridge & 55.7 & 0.067 & - & - & - & - & - & - & 0.025 & 0.030 & - & - & - & 0.878 & - & 5.2 & 6.2 \\
\hline 9 & Hinashiro Bridge & 35.0 & 0.544 & - & - & - & - & - & - & 0.029 & - & - & - & - & 0.428 & - & 13.3 & 8.4 \\
\hline 10 & Nagino Bridge & 66.5 & 0.015 & - & - & - & - & 0.008 & - & 0.927 & - & - & - & - & 0.050 & - & 12.3 & 10.3 \\
\hline 11 & Yoake Dam & 1435.8 & 0.022 & - & 0.006 & 0.101 & 0.003 & 0.316 & 0.215 & 0.322 & 0.005 & - & - & $<0.001$ & 0.006 & 0.003 & 18.1 & 18.6 \\
\hline 12 & Chayanose Bridge & 73.6 & 0.030 & - & - & - & - & - & - & 0.843 & 0.033 & - & - & - & 0.094 & - & 13.5 & 10.0 \\
\hline 13 & Saburoumaru Bridge & 128.7 & - & - & - & - & - & 0.441 & 0.001 & 0.558 & - & - & - & - & - & - & 13.8 & 15.1 \\
\hline 14 & Nagafuchi Bridge & 1166.5 & 0.024 & - & 0.008 & 0.125 & 0.004 & 0.324 & 0.264 & 0.243 & 0.004 & - & - & $<0.001$ & - & 0.004 & 19.2 & 20.0 \\
\hline 15 & Kobuchi Bridge & 1116.8 & 0.025 & - & 0.008 & 0.129 & 0.004 & 0.332 & 0.276 & 0.216 & 0.004 & - & - & $<0.001$ & - & 0.004 & 20.5 & 20.2 \\
\hline 16 & Ichinomura Bridge & 442.8 & 0.057 & - & 0.021 & 0.133 & - & 0.231 & 0.558 & - & - & - & - & - & - & - & 22.1 & 21.7 \\
\hline 17 & Kyoushin Bridge & 315.7 & 0.056 & - & 0.029 & 0.118 & - & 0.214 & 0.583 & - & - & - & - & - & - & - & 22.3 & 22.8 \\
\hline 18 & Higashikochi Bridge & 113.7 & - & - & 0.060 & - & - & 0.243 & 0.697 & - & - & - & - & - & - & - & 25.8 & 25.6 \\
\hline 19 & Kuguriishi Bridge & 45.2 & 0.002 & - & - & 0.455 & - & - & 0.543 & - & - & - & - & - & - & - & 27.0 & 26.8 \\
\hline 20 & Miake Bridge & 480.7 & 0.098 & 0.002 & - & - & - & 0.009 & - & 0.378 & - & 0.010 & - & - & 0.499 & 0.004 & 7.4 & 8.1 \\
\hline 21 & Isodori Weir & 468.9 & 0.076 & 0.002 & - & - & - & 0.009 & - & 0.388 & - & 0.011 & - & - & 0.511 & 0.004 & 6.3 & 8.1 \\
\hline 22 & Seiten Bridge & 473.0 & 0.084 & 0.002 & - & - & - & 0.009 & - & 0.384 & - & 0.010 & - & - & 0.507 & 0.004 & 7.3 & 8.1 \\
\hline 23 & Sankaizeki Bridge & 12.0 & 0.544 & - & - & - & - & - & - & - & - & - & - & - & 0.456 & - & 7.9 & 8.3 \\
\hline 24 & Yamashita Bridge & 25.0 & - & 0.031 & - & - & - & - & - & - & - & - & - & - & 0.969 & - & 5.9 & 5.7 \\
\hline 25 & Nakadouri Bridge & 49.8 & 0.046 & - & - & - & - & - & - & - & - & 0.098 & - & - & 0.856 & - & 6.4 & 6.3 \\
\hline 26 & Kamiyabegawa Bridge & 143.4 & 0.044 & - & - & - & - & 0.004 & - & 0.438 & - & - & - & - & 0.514 & - & 8.1 & 8.0 \\
\hline 27 & Hoshinogawa Bridge & 215.5 & 0.010 & - & - & - & - & 0.016 & - & 0.552 & - & - & - & - & 0.412 & 0.009 & 7.7 & 8.6 \\
\hline 28 & Matsuze Dam & 83.7 & - & - & - & - & - & - & - & 0.733 & - & - & - & - & 0.244 & 0.022 & 7.9 & 9.3 \\
\hline 29 & Bridge & 49.6 & - & - & - & - & - & - & - & 0.810 & - & - & - & - & 0.190 & - & 8.1 & 9.6 \\
\hline 30 & Miikekantakunai Bridge & 9.2 & 0.591 & - & - & - & - & - & - & - & - & - & - & - & 0.680 & - & 7.7 & 8.5 \\
\hline 31 & Tsukazaki Bridge & 4.8 & 0.320 & - & - & - & - & - & - & - & - & - & - & - & 0.649 & - & 10.5 & 7.2 \\
\hline 32 & Shinkawa Bridge & 18.5 & 0.569 & - & - & - & - & - & - & - & 0.147 & - & - & - & 0.285 & - & 8.2 & 9.1 \\
\hline 33 & Miikedenryokusyoyokoi Weir & 13.2 & 0.576 & - & - & - & - & - & - & - & 0.205 & - & - & - & 0.219 & - & 9.5 & 9.4 \\
\hline 34 & Shindoumen Bridge & 11.8 & 0.771 & - & - & - & - & - & - & - & 0.218 & - & - & - & 0.011 & - & 9.4 & 10.4 \\
\hline 35 & Okogaeri Bridge & 7.6 & 0.661 & - & - & - & - & - & - & - & 0.339 & - & - & - & - & - & 11.2 & 10.5 \\
\hline 36 & Satsuki Bridge & 7.5 & 0.999 & - & - & - & - & 0.001 & - & - & - & - & - & - & - & - & 10.9 & 10.5 \\
\hline 37 & Miiketetsudoukako Bridge & 64.5 & 0.264 & - & - & - & - & 0.298 & - & - & 0.293 & - & - & - & 0.144 & - & 12.9 & 12.9 \\
\hline 38 & Babamachishusui Weir & 60.5 & 0.212 & - & - & - & - & 0.320 & - & - & 0.314 & - & - & - & 0.155 & - & 15.9 & 13.1 \\
\hline \multicolumn{17}{|c|}{ (b) Sampling site for validation } & \multicolumn{2}{|c|}{ Unit $\left(\mathrm{mg} \cdot \ell^{-1}\right)$} \\
\hline \multirow{2}{*}{ Site No. } & \multirow{2}{*}{ Sampling site } & \multirow{2}{*}{$\begin{array}{c}\text { Tota area } \\
\left(\mathrm{km}^{2}\right)\end{array}$} & \multicolumn{14}{|c|}{ Ratio of divided areas by geological categories (-) } & \multirow{2}{*}{$\begin{array}{l}\text { Observed } \\
\text { DSi value } \\
\end{array}$} & \multirow{2}{*}{\begin{tabular}{|l|} 
Predicted \\
DSi value \\
\end{tabular}} \\
\hline & & & 1 & 4 & 6 & 8 & 9 & 10 & 12 & 13 & 16 & 17 & 18 & 20 & 21 & 22 & & \\
\hline V1 & Zendo & 99.9 & 0.499 & - & - & - & - & 0.157 & - & 0.131 & - & - & 0.213 & - & - & - & 13.0 & 12.1 \\
\hline V2 & Omiya Bridge & 580.2 & 0.005 & - & - & 0.110 & 0.365 & 0.502 & - & 0.008 & - & $<0.001$ & - & 0.008 & - & - & 15.5 & 19.8 \\
\hline V3 & Sugikawachi Bridge & 25.7 & 0.018 & - & - & 0.731 & - & 0.251 & - & - & - & - & - & - & - & - & 20.6 & 41.1 \\
\hline
\end{tabular}

Table 2 Geological categories classified by rock type and geologic age

\begin{tabular}{c|l|c}
\hline Category & Rock type & Geologic age \\
\hline 1 & Sedimentary rocks & All \\
\hline 2 & Accretionary complexes, Mainly sedimentary rocks & Pre-Quaternary \\
\hline 3 & Accretionary complexes, Volcanic rocks & Pre-Quaternary \\
\hline 4 & Accretionary complexes & Pre-Quaternary \\
\hline 5 & Accretionary complexes, Plutonic rocks & Pre-Quaternary \\
\hline 6 & Volcanic rocks, Debris & Quaternary \\
\hline 7 & Volcanic rocks, Non-alkali, Felsic, Intrusive & Pre-Quaternary \\
\hline 8 & \multirow{2}{*}{ Volcanic rocks, Non-alkali, Felsic } & Quaternary \\
\cline { 3 - 3 } 9 & & Pre-Quaternary \\
\hline 10 & \multirow{2}{*}{ Volcanic rocks, Non-alkali, Pyroclastic flows } & Quaternary \\
\cline { 3 - 3 } & Pre-Quaternary \\
\hline 12 & \multirow{2}{*}{ Volcanic rocks, Non-alkali, Mafic } & Quaternary \\
\cline { 3 - 3 } & Pre-Quaternary \\
\hline 13 & Volcanic rocks, Alkali, Felsic & Pre-Quaternary \\
\hline 15 & Volcanic rocks, Alkali, Mafic & All \\
\hline 16 & Plutonic rocks, Felsic & Pre-Quaternary \\
\hline 17 & Plutonic rocks, Felsic and Mafic & Pre-Quaternary \\
\hline 18 & Plutonic rocks, Mafic & Pre-Quaternary \\
\hline 19 & Plutonic rocks, Migmatitic & Pre-Quaternary \\
\hline 20 & Metamorphic rocks, Low to medium pressure type & Pre-Quaternary \\
\hline 21 & Metamorphic rocks, High pressure type & Pre-Quaternary \\
\hline 22 & Water area &
\end{tabular}

\section{3. 結果と考察}

\section{1 DSi 調査結果}

DSi 調査の結果を Table 1 (a) に示す。

各地点の平均值についてみてみると, 最小值は, 屋形 原橋（No.8）で, $5.2 \mathrm{mg} \cdot \ell^{-1}$, 最大值は, 潜石橋（No.19）
で, $27.0 \mathrm{mg} \cdot \ell^{-1}$ であり，その差は 5.2 倍であった。

流域別にみると，筑後川流域（No.1～19）について は, 筑後川の本流及び, その上流に位置する玖珠川（No.2, 11, 14 ～19）において DSi 濃度が $15 \mathrm{mg} \cdot \ell^{-1}$ 以上と高く なっていた。

矢部川流域 $(\mathrm{No} .20 \sim 29)$ においては, $10 \mathrm{mg} \cdot \ell^{-1}$ 未 満で他の地点と比較して DSi の值が低い傾向を示した。

大牟田市内河川（No.30～38）については，およ そ $10 \mathrm{mg} \cdot \ell^{-1}$ 程度の值であったが, 三池鉄道河口鉄橋 (No.37) 及び馬場町取水堰 (No.38) の 2 力所については, 同地点群と比較して值が高かった。

\section{2 地質調査結果}

地質調査の結果を Table 3 に示す。ここでは各地点の 流域内地質の各カテゴリー面積割合を算定したものを記 載する。Table 2 では地質を 22 のカテゴリーに区分した が, 今回対象とした有明海北東部流域では, そのうちの 14 カテゴリーが含まれていた。

結果をみると, 流域内の地質区分は, 流域毎に異なる 地質特性を有していることが分かる。

筑後川水系（No.1-19）においては，その本川及び上 流部（No.2, 11-19）と他の支川とで，流域地質が明確に 異なっている。本川及び上流部に属する地点の流域では 火山岩の割合が高いのに対し, 支川に属する地点の流域 では火山岩の割合が低い。

矢部川水系（No.20-29）においては，第三紀以前火山 岩類 (非アルカリ珪長質苦鉄質) [Cat.13] や変成岩類（高 
圧型）[Cat.21］の占める割合が高い。

大牟田市内河川（No.30-38）においては, 堆積岩類 [Cat.1], 深成岩類（珪長質） [Cat.16], 変成岩類（高圧型） [Cat.21］の占める割合が高い。特に，諏訪川の観測地 点である三池鉄道河口鉄橋（No.37）及び，馬場町取水 堰（No.38）では, 周辺の流域とは異なり，その流域内 に第四紀火山岩類（非アルカリ火砕流） [Cat.10］の地 質が 3 割程度含まれている。

\section{3 DSi 濃度の予測式}

DSi 調査及び地質調査の結果から, 各地点の DSi 濃度 は，その地点の流域内の地質区分を反映したものとなっ ていることが想定される。そこで Table 1 (a) の各地点の 平均 DSi 濃度を目的変数とし, Table 3 中の各流域の各 地質区分面積割合を説明変数とする, 以下の重回帰式が 成り立つと仮定する。

$$
y_{j}=b_{0}+\sum_{k=1}^{13} b_{k} x_{j k}
$$

ここで, $y j$ : 流域 $j$ における平均 DSi 濃度の予測值 $\left(\mathrm{mg} \cdot \ell^{-1}\right), b_{0}$ : 定数, $b_{k}$ : 地質カテゴリー $k$ の偏回帰係数, $x_{j k}$ : 流域 $j$ に含まれる地質カテゴリー $k$ の面積割合であ る。その際，水域 [Cat.22] については説明変数から除 外して, 13 のカテゴリーに対して解析を実施した。なお， 予測式の有効な変数選択を目的として，ステップワイズ 回帰法により自由度調整済寄与率が高くなるように変数 を選択した。

同法によって選択されたカテゴリー毎の標準偏回帰係 数 $\beta_{k}$, 偏回帰係数 $b_{k}, \mathrm{t}-$ 值, 及び $\mathrm{p}$-值の算定結果を Table 4 に示す。有意な説明変数として選択されたのは 5 つのカテゴリーで，火山岩類（岩屑） [Cat.6]，第四紀 非アルカリ珪長質 [Cat.8], 第四紀火山岩類（非アルカ リ火砕流) [Cat.10], 第四紀火山岩類 (非アルカリ珪長質・ 苦鉄質） [Cat.12], 変成岩類 (高圧型) [Cat.21］であった。

この際, 得られた標準偏回帰係数から, 目的変数に対 する各説明変数の寄与を相対的に評価可能である。こ れによると DSi 濃度に対する寄与が大きい地質分類は, 順に第四紀非アルカリ珪長質 [Cat.8], 火山岩類（岩屑） [Cat.6]，第四紀火山岩類（非アルカリ火砕流） [Cat.10] であった。

地質的にみると， [Cat.8］が [Cat.12］よりも寄与が 大きい，すなわちマフィック火成岩類よりもフェルシッ ク火成岩類の寄与が大きい傾向がある。この理由とし て, 岩石の化学組成からみて, フェルシックな岩石には

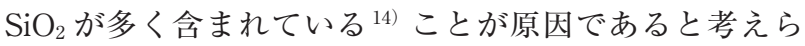
れる。

Table 4 The results of multiple regression analysis where $\beta_{k}=$ standard partial regression coefficient and $b_{k}=$ partial regression coefficient

\begin{tabular}{crrrr}
\hline Category & $\beta_{k}$ & \multicolumn{1}{c}{$b_{k}$} & $t$-value & $p$-value \\
\hline- & & 10.500 & 20.488 & 0.000 \\
6 & 0.458 & 237.579 & 1.751 & 0.090 \\
8 & 0.552 & 38.607 & 2.740 & 0.010 \\
10 & 0.241 & 10.384 & 4.279 & 0.000 \\
12 & -0.080 & -2.404 & -0.226 & 0.822 \\
21 & -0.245 & -4.906 & -4.465 & 0.000 \\
\hline
\end{tabular}

年代的にみると, 第四紀の火山岩地質を有する割合の 高い流域において, DSi 濃度が高くなること傾向にある。 この理由として，第四紀火山岩地質が，その他の流域に 比べ保水力が高いことが影響していると考えられる。第 四紀火山岩地質の高保水力については, 過去の研究によ れば, 流域内において同地層の分布面積が大きいほど渴

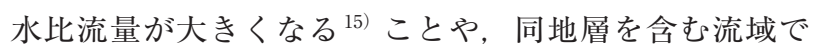
はその低減定数が小さい16,17)ことから明らかにされてい る。すなわち, 第四紀火山岩地質では, その高保水力に より, 水一岩石間の接触時間が長くなり, その結果 DSi 濃度が高くなると考えられる。

三池鉄道河口鉄橋 (No.37) 及び, 馬場町取水堰 (No.38) の流域においても第四紀火山岩類（非アルカリ火砕流） [Cat.10］が分布しており, これらの地点でDSi 濃度が 高い現象を裏付ける結果となった。

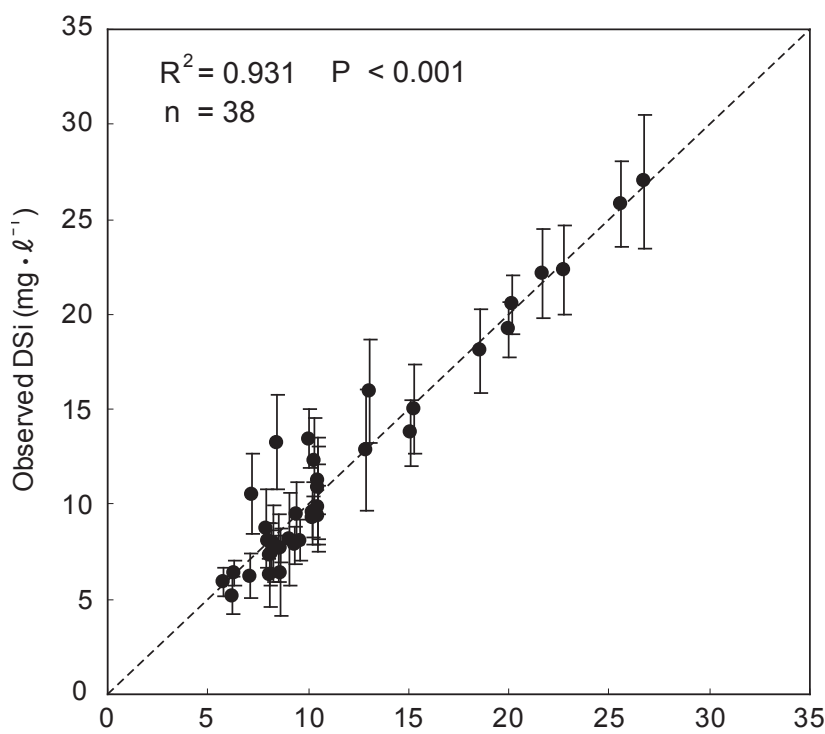

Fig. 2 Comparison of the observed values of DSi at sampling sites for calculation with the calculated results using eq.(1). Error bars represent one standard deviation of the observed DSi. The dashed line represents a slope of 1.0.

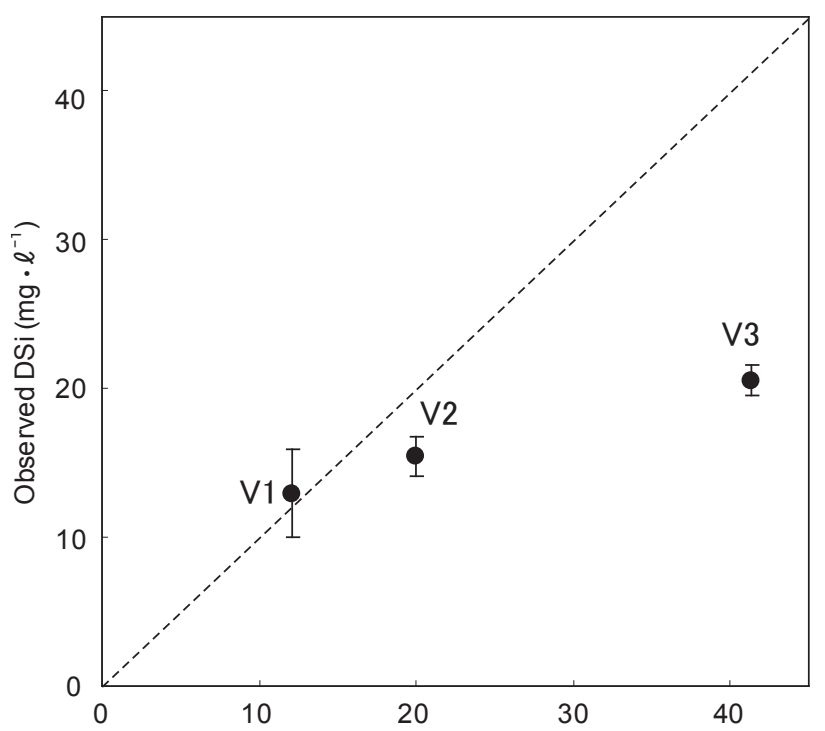

Fig. 3 Comparison of the observed values of DSi at sampling sites for validation with the results calculated using eq.(1). Error bars represent one standard deviation of the observed DSi. The dashed line represents a slope of 1.0. 
一方で筑後川下流付近の流域に多く含まれている堆積 岩類 [Cat.1］については, DSi 濃度に対する寄与が小 さい結果となった。さらに柳野橋 (No.10), 茶屋の瀬橋 (No.12) のように，火山岩地質であっても第三紀以前の 地質が多く占める場合 (この場合, 非第四紀火山岩類 (非 アルカリ珪長質・苦鉄質）（Cat.13］）には，その地質の DSi 濃度への寄与が小さい為に, DSi 濃度も低かった。

重回帰式から得られた予測值を Table 3 中に示す。ま た予測值と観測值を比較したものを Fig. 2 に示す。寄与 率は 0.931 と高く, 予測值と実測值は,ほぼ一致していた。 このことからも, 地点間の DSi 濃度変動は, 地質由来 であることが再確認された。

一方でDSi の寄与としては，地質由来のような自然 系の寄与以外にも, 生活系・事業場系 ${ }^{18)}$ ・農業系 ${ }^{19)}$ 等 の人為的な寄与や停滞水域における珪藻類の吸収 20 23) の影響も考えられる。今回の結果によれば, 流域地質で DSi 濃度がある程度説明出来たことにより，これらの人 為的影響は小さいものと推察される。ただし, Fig. 2 に よると幾つかの地点においては, 実測值と計算值との間 に不整合がみられる。この不整合の原因として上述の人 為的影響も考えられる。今後は，このような人為的影響 に対する更なる知見の蓄積が必要である。

\section{4 モデルの検証}

モデルを他の流域に応用することで，その有効性につ いての検証を実施した。対象とした流域は，モデル作成 に用いた流域内の 3 地点 (Site No.V1-V3) である。 3 地点の位置については Fig. 1 に, それらの諸元と調査期 間を Table 1(b) に示す。

これらの 3 地点の実測 DSi 濃度と流域地質調査結果 を合わせて Table 3(b) に示す。また検証地点の DSi 濃度 測定結果と，今回作成した重回帰モデルにより予測した DSi 濃度とを比較したものを Fig. 3 に示す。

V1（巨瀬川, 善導寺橋）については, ほぼ予測通り であるが, V2 (大山川, 大宮橋) については実測值よ りも高めの予測值となっている。またV3（山浦川，杉 河内橋）については実測值よりも 2 倍近く高い予測值と なった。

この予測值との解離する原因については, それらの地 点が有する, DSi 濃度に寄与の大きい [Cat.8］，[Cat.10］ の面積比率に由来していると考えられる。すなわち, V3 では [Cat.8］の面積比率が 0.731 であるが, 式を作 成した際の [Cat.8］の面積比率の範囲は 0.064-0.455 で あり,これを大幅に超過していた。また V2 では[Cat.10] の面積比率が 0.502 であるが，［Cat.10］の面積比率の範 囲は 0.001-0.441であり, これもその範囲を超過してい た。このようにDSi 濃度に対し寄与率の高い地質カテ ゴリーが，式作成時の地質割合を超過している場合には 予測值と実際との值が解離する傾向にある。

今回の結果により, 有明海北東部の任意の地点の DSi 濃度は, 流域の地質面積比率が一定の条件下において, 重回帰式により予測可能であることが明らかとなった。 また，他の流域についても，同様の手法で重回帰式を作 成すれば, DSi 濃度の予測は可能であると考えられる。 将来的には本研究の結果を用いることで, 有明海におけ る定常時の DSi 流入負荷量を想定することが可能にな ると考えられる。

\section{4.まと め}

本研究では, 環境基準点を含む有明海流入河川 38 地 点において DSi 濃度を测定しその実態を調査するとと もに, 数值地質図を用いて各地点における DSi 濃度の 予測を試みた。この研究から得られた主な結論を以下に 示す。

1) 重回帰分析により予測されたDSi 濃度は, 実際の 值と近いもので寄与率も 0.931 と高かった。このこ とから有明海北東部流域内の DSi 濃度の空間的変 動は, 流域地質由来であることが再確認された。

2 ) DSi 濃度に寄与の大きい地質は, 寄与の大きい順に 第四紀非アルカリ珪長質, 火山岩類の岩屑, 第四紀 火山岩類（非アルカリ火砕流）であった。

3 ) 有明海北東部における, 任意の地点の河川水中の DSi 濃度は, その流域内における地質分布によりお およその予測が可能である。

\section{謝 辞}

本研究の遂行にあたり, 福岡県環境部環境保全課, 各 保健福祉環境事務所の皆様に数々の便宜を図って頂い た。また本研究の一部は, H21 年度環境省環境技術開発 推進費により行われたものであり，ここに謝意を表す。 （原稿受付 2009年 8 月 28 日) （原稿受理 2010年 2 月 10 日）

\section{参 考 文 献}

1 ）環境省有明海 -八代海総合調查評価委員会 (2007) 有明海 八代海総合調查委員会報告書.

2 ）川口修, 山本民次, 松田治, 橋本俊也 (2004) 水質の長期変動 に基づく有明海に扔けるノリおよび珪藻プランクトンの増殖制限 元素の解明. 海の研究 13 (2), pp.173-183.

3 ） 小林純（1961）日本の河川の平均水質とその特徴に関する研 究. 農学研究 48, pp.63-106.

4 ）熊谷博史, 田中義人, 松尾宏, 白川ゆかり（2008）有明海北東 部流域からの溶存態ケイ素の流出と有明海への影響. 第 23 回全 国環境研究所交流シンポジウム予稿集, pp.12-15.

5 ）鹿園直建（2002）化学的風化作用の河川水水質特に溶存シリ 力濃度に与える影響。地学雑誌 111 (1), pp.55-65.

6 ) Meybeck, M. (1987) Grobal chemical weathering of surficial rocks estimated from river dissolved loads. American journal of science 287, pp.401-428.

7 ）柴田未来, 長井正博, 片山幸士（2008）豊川流域に扔けるケイ 酸及び主要溶存成分の濃度変化. 第 42 回日本水環境学会年会公 演集, p.226.

8 ）社団法人日本水道協会（2001）上水試験方法.

9 ） 日本規格協会 (2008) JIS ハンドブック 53 環境測定 II (水質).

10) Kennedy, V. (1971) Silica variation in stream water with time and discharge. Nonequilibrium Systems in Natural Water Chemistry. Nonequilibrium Systems in Natural Water Chemistry. American Chemical Society, Advances in Chemistry Series No. 106. ACS, pp.94-130.

11）産業技術総合研究所地質調查総合センター (2003) 100 万分 の 1 日本地質図第 3 版, CD-ROM 第 2 版, 数值地質図 G-1.

12）国土交通省 国土数值情報（流路デー夕）.

13）国土交通省 国土数值情報（流域・非集水域（面）デー夕).

14）杉村新, 中村保夫, 井田喜明（1988）図説地球科学, 岩波書店, 東京.

15）高橋裕, 安藤義久, 井上誠一（1981）表日本の山地河川の流 況特性に関する統計的研究. 第 25 回水理講演会論文集, pp.209214.

16）安藤義久, 高橋裕, 伊藤孝（1981）山地河川の地下水流出の 
派減特性それに対する流域地質の効果. 第 23 回水理講演会論文 集, pp.175-181.

17）高橋裕，安藤義久，伊藤孝，伊藤和央（1983）山地河川の低水 流出の減水特性に関する研究. 土木学会論文報告集 $337, \mathrm{pp} .75-$ 82.

18）熊谷博史，田中義人，松尾宏，白川ゆかり（2008）特定事業場 排水中に含まれる溶存態ケイ素の実態調査. 平成 19 年度社団法 人日本水環境学会九州支部研究発表会講演概要集, pp.5-6.

19）高橋英一（1987）ケイ酸植物と石灰植物一作物の個性を探る-, 農山漁村文化協会, 東京.
20) Humborg, C., Ittekkot, V., Cociasu, A., Bodungen, B.v. (1997) Effect of Danube River dam on Black Sea biogeochemistry and ecosystem structure. Nature 386, pp.385-388.

21）原島省（2003）陸水域におけるシリカ欠損と海域生態系の変 質．水環境学会誌 26 (10), pp.621-625.

22) 田庚吴, 林到映, 千葉信男, 野村宋弘, 中野和典, 西村修 (2008) 河川における $\mathrm{Si}$ の挙動とその要因. 第 42 回日本水環境学会年会 公演集, p.225.

23）井上直也，赤木右（2006）多摩川に扔けるケイ素収支にあたえ るダム拉よび下水処理場の影響．地球化学 40, pp.137-145. 